\title{
The effect of petroleum-derived substances on the dynamic of sitona weevils Sitona spp. (Coleoptera: Curculionidae) feeding
}

\author{
Wpływ związków ropopochodnych na dynamikę żerowania \\ oprzędzików Sitona spp. (Coleoptera: Curculionidae)
}

\author{
Milena Rusin*, Janina Gospodarek, Barbara Biniaś
}

\begin{abstract}
Summary
The aim of the study was to determine the effect of petrol, diesel fuel, used engine oil and ZB-01 product supporting bioremediation on Sitona spp. feeding. The experiment was conducted in 2013 and 2015 at the Experimental Station of the University of Agriculture in Kraków. The experimental field in 2010 was contaminated with petroleum-derived substances in quantity of $6000 \mathrm{mg}$ per $1 \mathrm{~kg}$ of dry mass and subjected to bioremediation (with especially prepared ZB-01 product). The evaluation of Sitona spp. feeding intensity was conducted by measuring the loss of leaf blade, the surface area consumed by insects and by counting the damaged and undamaged leaves. The results of the experiment showed that the oils contributed to the reduction of the number of plants damaged by beetles and also reduced the consumed surface area. The effect of petrol varied and depended on the year when the study was conducted. Applied bioremediation in 2013 contributed to the reduction of beetles feeding while in 2015 an inverse relationship was reported.
\end{abstract}

Key words: petroleum-derived substances; petrol; engine oil; diesel fuel; sitona weevils; broad bean

\section{Streszczenie}

Celem badań było określenie oddziaływania benzyny, oleju napędowego i przepracowanego oleju silnikowego oraz bioremediacji wspomaganej na żerowanie oprzędzików (Sitona spp.). Doświadczenie przeprowadzono w 2013 i 2015 roku na obszarze Stacji Doświadczalnej Uniwersytetu Rolniczego w Krakowie. Obszar ten w 2010 roku zanieczyszczono związkami ropopochodnymi w ilości $6000 \mathrm{mg}$ na $\mathrm{kg}$ suchej masy gleby i poddano bioremediacji (z użyciem specjalnie przygotowanego preparatu ZB-01). Ocenę intensywności żerowania oprzędzików przeprowadzono przez pomiar ubytku blaszki liściowej, powierzchni wyżerek oraz policzenie liści uszkodzonych i nieuszkodzonych. Na podstawie badań stwierdzono, że oleje najczęściej powodowały zmniejszenie liczby roślin uszkodzonych przez chrząszcze i zmniejszenie powierzchni wyżerek liści. Oddziaływanie benzyny było zmienne, zależne od roku, w którym przeprowadzono badania. Zastosowana bioremediacja w 2013 roku spowodowała ograniczenie żerowania chrząszczy, a w 2015 roku odnotowano odwrotną zależność.

Słowa kluczowe: związki ropopochodne; benzyna; olej silnikowy; olej napędowy; oprzędziki; bób

\footnotetext{
Uniwersytet Rolniczy im. Hugona Kołłątaja w Krakowie

Al. Mickiewicza 21, 31-120 Kraków

*corresponding author: milena_rusin@wp.pl
} 


\section{Wstęp / Introduction}

Ropa naftowa i substancje ropopochodne, w związku $\mathrm{z}$ szerokim ich zastosowaniem, występują w różnych elementach środowiska. Wraz ze wzrostem mechanizacji i urbanizacji coraz częściej dochodzi do przekroczenia dopuszczalnych norm tych ksenobiotyków w środowisku przyrodniczym (Onwurah i wsp. 2007; Das i Chandran 2011). Do najczęstszych przyczyn zanieczyszczenia gleby substancjami ropopochodnymi możemy zaliczyć: wycieki związane z uszkodzeniem rurociągów, zbiorników magazynowych, zerwanie głowic z szybów wydobywczych czy wypadki związane z transportem (Ogbo 2009; Ziółkowska i Wyszkowski 2010). Obecność tych związków w glebie jest jednym z czynników, który przyczynia się do znacznego obniżenia jej żyzności, a co za tym idzie do pogorszenia wydajności roślin uprawnych (Liste i Felgentreu 2006; Houshmandfar i Asli 2011; Gbadebo i Adenuga 2012). Związane jest to $\mathrm{z}$ ich zdolnością do modyfikowania właściwości fizycznych, chemicznych i biologicznych gleby (Caravaca i Rodán 2003; Iturbe i wsp. 2007; Wyszkowska i Wyszkowski 2010; Sutton i wsp. 2013). Bioremediacja jest jedną z najbardziej skutecznych metod oczyszczania gleb zanieczyszczonych substancjami ropopochodnymi. Polega ona na wykorzystaniu organizmów żywych do rozkładu szkodliwych związków, co jest możliwe dzięki zdolnościom niektórych mikroorganizmów (bakterii, grzybów) do wykorzystania związków ropopochodnych jako źródła węgla i energii, powodując ich rozpad na związki nietoksyczne (Haritash i Kaushik 2009; Milić i wsp. 2009).

Wpływ substancji ropopochodnych na wzrost i rozwój roślin, a także ich wpływ na inne organizmy, które są bezpośrednio narażone na kontakt z zanieczyszczeniami, jest dość dobrze poznany, jednak w literaturze brak informacji o wpływie pośrednim tych związków z zanieczyszczonej gleby poprzez roślinę na fitofagi. Oprzędziki (Sitona spp.) są groźnymi szkodnikami roślin z rodziny Fabaceae, mogącymi przyczyniać się do znacznych strat w plonie (Strażyński 2013). Dorosłe osobniki wygryzają charakterystyczne, koliste zatoki na brzegach blaszki liściowej, przyczyniając się do zmniejszenia powierzchni asymilacyjnej. Larwy tego szkodnika żerują na brodawkach i włośnikach korzeniowych zmniejszając ilość azotu wiązanego przez rośliny oraz zaburzając gospodarkę powietrzno-wodną (Dor'e i Meynard 1995; Corre-Hellou i Crozat 2005).
Celem przeprowadzonych badań było określenie oddziaływania zanieczyszczenia gleby benzyną, przepracowanym olejem silnikowym oraz olejem napędowym na dynamikę żerowania oprzędzików na bobie (Vicia faba L.). Ponadto zbadano, jak na intensywność żerowania analizowanych szkodników wpływa proces bioremediacji wspomaganej użyciem preparatu mikrobiologicznego ZB-01.

\section{Materiały i metody / Materials and methods}

Doświadczenie zostało przeprowadzone w maju 2013 i 2015 roku na obszarze Stacji Doświadczalnej Uniwersytetu Rolniczego w Mydlnikach, położonej niedaleko Krakowa $\left(50^{\circ} 5^{\prime} 5,04^{\prime \prime} \mathrm{N} 19^{\circ} 51^{\prime} 13,47^{\prime} \mathrm{E}\right)$. Był to obszar porośnięty trawą, koszoną dwa razy podczas sezonu wegetacyjnego. W listopadzie 2009 roku gleba rodzima została umieszczona $\mathrm{w}$ kontenerach o pojemności $1 \mathrm{~m}^{3}$ wraz z zachowaniem naturalnego układu warstw. Kontenery zostały wkopane do gleby tak, by ich górna krawędź znajdowała się równo z powierzchnią gleby. Każdy z nich wyposażony był w przewód prowadzący na powierzchnię, aby umożliwić odpompowywanie nadmiaru wody, a także $\mathrm{w}$ trzy plastikowe rurki w celu odpowiedniego napowietrzenia gleby, co jest niezbędne do prawidłowego przebiegu procesu bioremediacji (rys. 1). Gleba w kontenerach została pozostawiona bez ingerencji na okres ośmiu miesięcy, aby umożliwić jej powrót do naturalnej sprawności biologicznej. W czerwcu 2010 roku gleba w kontenerach została sztucznie zanieczyszczona różnymi ropopochodnymi w ilości $6000 \mathrm{mg}$ na $1 \mathrm{~kg}$ suchej masy gleby. Po upływie tygodnia połowa kontenerów z poszczególnych obiektów została poddana procesowi bioremediacji wspomaganej poprzez dodanie do gleby biopreparatu ZB-01, zawierającego w swoim składzie bakterie $\mathrm{z}$ rodzajów: Bacillus, Pseudomonas, Moraxella, Stenotrophomonas, Acinetobacter, Corynebacterium, Methylobacterium, Alcaligenes, Oligella, Morganella. Procedurę użycia biopreparatu powtórzono wiosną 2011 roku. Kontrolę stanowiła gleba niezanieczyszczona. Utworzono osiem obiektów: gleba zanieczyszczona benzyną bez użycia biopreparatu (B 0R) i z jego użyciem (B R); gleba zanieczyszczona olejem napędowym bez biopreparatu (ON 0R) i z biopreparatem (ON R); gleba zanieczyszczona zużytym olejem silnikowym bez biopreparatu (OS OR) i z biopreparatem (OS R); gleba niezanieczyszczona bez biopreparatu (K 0R)

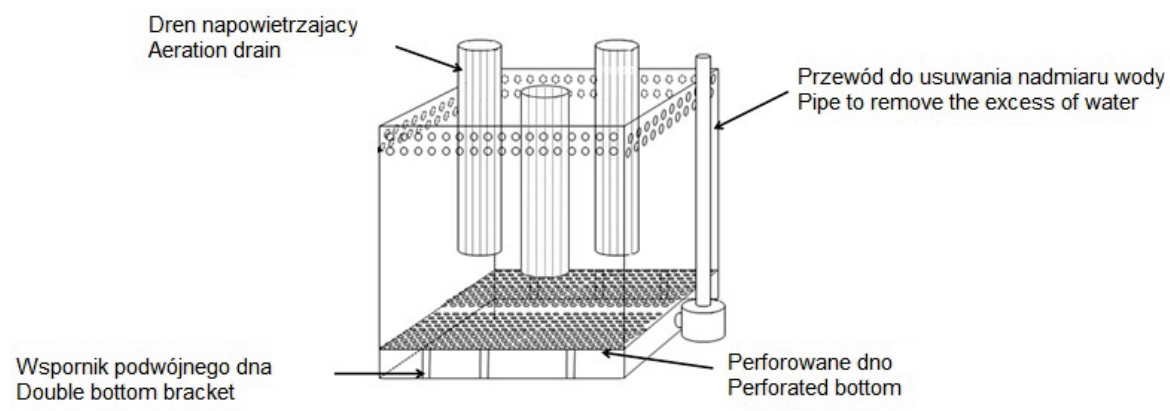

Rys. 1. Schemat budowy kontenera zastosowanego w doświadczeniu

Fig. 1. Scheme of container construction used in the experiment 
i z biopreparatem (K R). Doświadczenie założono w czterech powtórzeniach (łącznie 32 kontenery) zgodnie $\mathrm{z}$ metodą losowanych bloków. Przez kolejne lata, aż do 2013 roku, gleba w kontenerach była pozostawiona bez ingerencji, umożliwiając jej naturalną sukcesję roślinną. Nasiona bobu odmiana Windsor Biały zostały wysiane w kontenerach na początku kwietnia 2013 r. (tj. po upływie trzech lat od momentu zanieczyszczenia i zastosowania bioremediacji po raz pierwszy) i 2015 r. (odpowiednio po pięciu latach) w liczbie 30 sztuk na kontener po uprzednim przygotowaniu gleby (tj. wzruszeniu i poddaniu nawożeniu). W 2013 roku zastosowano przedsiewne nawożenie polifoską wprowadzając do gleby: $2,88 \mathrm{~g} \mathrm{~N}, 8,64 \mathrm{~g} \mathrm{P}_{2} \mathrm{O}_{5}$ i 8,64 g K $\mathrm{K}_{2} \mathrm{O}$ na kontener, $\mathrm{z}$ kolei w 2015 roku zastosowano przedsiewne nawożenie azofoską wprowadzając do gleby: 5,32 g N, 2,44 g P $\mathrm{O}_{5}$ i 6,84 g K $\mathrm{g}_{2} \mathrm{O}$. Nawożenie było jednakowe we wszystkich obiektach, a dawkę ustalono na podstawie zaleceń producenta nawozu. W 2014 roku w kontenerach uprawiano pszenicę ozimą. Zdolność kiełkowania nasion bobu zarówno w 2013, jak i w 2015 roku we wszystkich analizowanych obiektach była podobna i kształtowała się w granicach od 90 do 100\%.

Ocena intesywności żerowania oprzędzików była przeprowadzana w każdym sezonie czterokrotnie, od momentu zauważenia pierwszych uszkodzeń na wschodzących roślinach, z częstotliwością jeden raz w tygodniu. W 2013 roku obserwacje rozpoczęto 8 maja, z kolei w 2015 roku 4 maja. Analizę przeprowadzono przez pomiar ubytku powierzchni liści (przez odniesienie powierzchni półkolistych wyżerek powodowanych przez imago Sitona spp. na liściu, obliczonej $\mathrm{w} \mathrm{mm}^{2} \mathrm{w}$ odniesieniu do całkowitej powierzchni liścia), powierzchni wyżerek oraz przez policzenie liści uszkodzonych i nieuszkodzonych. Ocena powierzchni uszkodzeń powodowanych przez chrząszcze została wykonana $\mathrm{z}$ wykorzystaniem papieru milimetrowego dla obliczenia powierzchni liścia i powierzchni wyżerek na wszystkich liściach $\mathrm{z}$ wybranych losowo 10 roślin z każdego z kontenerów. W każdym terminie obserwacje prowadzono na tych samych, oznaczonych wcześniej roślinach.

Uzyskane wyniki poddano analizie z wykorzystaniem programu STATISTICA v. 10.0. Istotność różnic między średnimi zbadano przeprowadzając analizę wariancji dwuczynnikowej (czynniki: rodzaj zanieczyszczenia $\times$ bioremediacja), a średnie zróżnicowano testem NIR Fishera $\operatorname{przy} \alpha=0,05$.

\section{Wyniki i dyskusja / Results and discussion}

Najwięcej liści uszkodzonych przez chrząszcze, w początkowym terminie prowadzonych obserwacji, zarówno po upływie trzech, jak i pięciu lat od momentu zanieczyszczenia gleby, odnotowano u roślin rosnących w obiekcie kontrolnym, $\mathrm{z}$ kolei oleje $\mathrm{w}$ największym stopniu ograniczały żerowanie tego szkodnika (różnice istotne statystycznie $\mathrm{W}$ porównaniu do kontroli odnotowano w przypadku oleju silnikowego w trzecim i piątym roku oraz oleju napędowego w piątym roku) (tab. 1). W późniejszych terminach również odnotowano zmniejszenie udziału liści uszkodzonych przez oprzędziki w wyniku zanieczyszczenia gleby olejami, jednak różnice istotne w odniesieniu do obiektu kontrolnego stwierdzono jedynie w piątym roku. Trzy lata po zanieczyszczeniu (tj. w 2013 roku) benzyna (począwszy od trzeciego terminu prowadzonych obserwacji) spowodowała istotny wzrost odsetka liści uszkodzonych przez oprzędziki u roślin rosnących na glebie zanieczyszczonej i po upływie czterech tygodni prowadzenia obserwacji udział liści uszkodzonych w tym obiekcie wynosił ponad $85 \%$, co stanowiło o ponad $20 \%$ więcej niż w kontroli. W 2015 roku (czyli po pięciu latach od momentu zanieczyszczenia) odnotowano odwrotna zależność - benzyna (podobnie, jak pozostałe związki ropopochodne) najczęściej ograniczała żerowanie oprzędzików i powodowała zmniejszenie odsetka liści uszkodzonych przez oprzędziki. Zastosowany biopreparat ZB-01, po upływie 3 lat od momentu pierwszego użycia, spowodował istotne zmniejszenie odsetka liści uszkodzonych przez oprzędziki (już od drugiego terminu prowadzonych obserwacji) w przypadku obiektu zanieczyszczonego olejem silnikowym i benzyną. W obiekcie kontrolnym działanie to przyczyniło się natomiast do wzrostu udziału liści uszkodzonych, z kolei w obiekcie zanieczyszczonym olejem napędowym początkowo ograniczało żerowanie analizowanego szkodnika, jednak pod koniec prowadzonych obserwacji odnotowano istotny wzrost procentu liści uszkodzonych w porównaniu do obiektu, gdzie nie zastosowano biopreparatu. Po upływie dwóch kolejnych lat biopreparat najczęściej powodował wzrost odsetka liści uszkodzonych u roślin rosnących w obiektach zanieczyszczonych wszystkimi substancjami ropopochodnymi.

Podobnie, jak w poprzednim analizowanym przypadku zarówno zanieczyszczenie gleby olejem silnikowym, jak i olejem napędowym przyczyniało się do zmniejszenia powierzchni wyżerek spowodowanych przez chrząszcze oprzędzików na liściach bobu odpowiednio po upływie trzech i pięciu lat od momentu zanieczyszczenia gleby (tab. 2). U roślin rosnących na glebie zanieczyszczonej benzyną w trzecim roku po zanieczyszczeniu obserwowano najczęściej wzrost powierzchni wyżerek w porównaniu do kontroli, z kolei w piątym roku - jej spadek. Zastosowany biopreparat w 2013 roku spowodował zmniejszenie powierzchni wyżerek powodowanych przez chrząszcze u roślin rosnących na glebie zanieczyszczonej olejem silnikowym i benzyną. W przypadku kontroli spowodował natomiast wzrost powierzchni wyżerek, z kolei u roślin rosnących na glebie zanieczyszczonej olejem napędowym nie miał istotnego wpływu na analizowany parametr. W 2015 roku (pięć lat od momentu zanieczyszczenia) odnotowano, że zastosowanie biopreparatu ZB-01 spowodowało istotny wzrost powierzchni wyżerek powodowanych przez chrząszcze u roślin rosnących na glebie zanieczyszczonej olejem silnikowym, olejem napędowym i benzyną $w$ niemal wszystkich terminach prowadzonych obserwacji. W obiekcie kontrolnym nie stwierdzono istotnego wpływu bioremediacji wspomaganej użyciem preparatu ZB-01 na analizowany parametr.

Zarówno olej silnikowy, jak i olej napędowy najczęściej nie miały istotnego wpływu na ubytek blaszki liściowej spowodowany żerowaniem oprzędzików zarówno po trzech, jak i pięciu latach po zanieczyszczeniu (tab. 3). 
Tabela 1. Wpływ związków ropopochodnych na liczbę liści uszkodzonych przez Sitona spp. po upływie 3 i 5 lat od momentu zanieczyszczenia gleby [\%]

Table 1. The effect of petroleum-derived substances on the number of leaves damaged by Sitona spp. 3 and 5 years after the soil contamination [\%]

\begin{tabular}{|c|c|c|c|c|c|c|c|c|}
\hline \multirow[b]{2}{*}{$\begin{array}{l}\text { Obiekt } \\
\text { Object }\end{array}$} & \multicolumn{2}{|c|}{$\begin{array}{c}1 \text { obserwacja } \\
1 \text { st observation }\end{array}$} & \multicolumn{2}{|c|}{$\begin{array}{c}2 \text { obserwacja } \\
\text { 2nd observation }\end{array}$} & \multicolumn{2}{|c|}{$\begin{array}{c}3 \text { obserwacja } \\
\text { 3rd observation }\end{array}$} & \multicolumn{2}{|c|}{$\begin{array}{c}4 \text { obserwacja } \\
\text { 4th observation }\end{array}$} \\
\hline & $\begin{array}{l}3 \text { rok po zanie- } \\
\text { czyszczeniu } \\
\text { 3rd year after } \\
\text { contamination }\end{array}$ & $\begin{array}{l}5 \text { rok po zanie- } \\
\text { czyszczeniu } \\
\text { 5th year after } \\
\text { contamination }\end{array}$ & $\begin{array}{c}3 \text { rok po zanie- } \\
\text { czyszczeniu } \\
\text { 3rd year after } \\
\text { contamination }\end{array}$ & $\begin{array}{l}5 \text { rok po zanie- } \\
\text { czyszczeniu } \\
5 \text { th year after } \\
\text { contamination }\end{array}$ & $\begin{array}{l}3 \text { rok po zanie- } \\
\text { czyszczeniu } \\
\text { 3rd year after } \\
\text { contamination }\end{array}$ & $\begin{array}{l}5 \text { rok po zanie- } \\
\text { czyszczeniu } \\
\text { 5th year after } \\
\text { contamination }\end{array}$ & $\begin{array}{c}3 \text { rok po zanie- } \\
\text { czyszczeniu } \\
\text { 3rd year after } \\
\text { contamination }\end{array}$ & $\begin{array}{l}5 \text { rok po zanie- } \\
\text { czyszczeniu } \\
\text { 5th year after } \\
\text { contamination }\end{array}$ \\
\hline OS OR & $53,57 \mathrm{ab}^{*}$ & $33,42 \mathrm{a}$ & $59,39 \mathrm{c}$ & $39,53 \mathrm{a}$ & $73,28 \mathrm{de}$ & $46,92 \mathrm{a}$ & $71,39 \mathrm{~cd}$ & $52,34 \mathrm{a}$ \\
\hline OS R & $55,63 \mathrm{ab}$ & $49,23 \mathrm{abc}$ & $39,45 \mathrm{a}$ & $54,28 \mathrm{bc}$ & $44,42 \mathrm{a}$ & $56,18 \mathrm{bc}$ & $52,19 \mathrm{a}$ & $62,42 \mathrm{bc}$ \\
\hline ON 0R & $60,00 \mathrm{abc}$ & $40,57 \mathrm{ab}$ & $59,15 \mathrm{c}$ & $46,97 \mathrm{ab}$ & $64,11 \mathrm{bc}$ & $49,54 \mathrm{a}$ & $58,85 \mathrm{ab}$ & $56,21 \mathrm{a}$ \\
\hline ON R & $50,42 \mathrm{a}$ & $47,52 \mathrm{ab}$ & $44,77 \mathrm{~b}$ & $54,90 \mathrm{c}$ & $61,46 b$ & $51,29 a b$ & $69,11 \mathrm{~cd}$ & $62,08 \mathrm{bc}$ \\
\hline B $0 \mathrm{R}$ & $69,58 \mathrm{~cd}$ & $48,63 \mathrm{abc}$ & 84,38 e & $42,47 \mathrm{a}$ & $87,46 \mathrm{f}$ & $53,66 \mathrm{ab}$ & $85,73 \mathrm{f}$ & $65,25 \mathrm{bc}$ \\
\hline B R & $63,96 \mathrm{bcd}$ & $52,28 \mathrm{bc}$ & $63,60 \mathrm{~cd}$ & $55,10 \mathrm{c}$ & $71,12 \mathrm{~cd}$ & $58,32 \mathrm{bc}$ & $76,19 \mathrm{de}$ & $59,87 \mathrm{ab}$ \\
\hline K 0R & $68,13 \mathrm{~cd}$ & $57,56 \mathrm{c}$ & $64,04 \mathrm{~cd}$ & $56,70 \mathrm{c}$ & $68,79 \mathrm{bcd}$ & $62,12 \mathrm{c}$ & $65,06 \mathrm{bc}$ & $69,16 \mathrm{c}$ \\
\hline K R & $70,63 \mathrm{~d}$ & $55,18 \mathrm{c}$ & $71,90 \mathrm{~d}$ & $54,89 \mathrm{c}$ & 75,88 ef & $58,67 \mathrm{bc}$ & 79,89 ef & $65,36 \mathrm{bc}$ \\
\hline
\end{tabular}

OS - gleba zanieczyszczona olejem silnikowym, ON - olejem napędowym, B - benzyną, K - kontrola, 0R - bez bioremediacji, R - z bioremediacją *wartości oznaczone różnymi literami w kolumnach różnią się od siebie istotnie przy $\alpha=0,05$

OS - soil contaminated with engine oil, ON - soil contaminated with diesel oil, B - soil contaminated with petrol, K - control soil, 0R - without bioremediation, $\mathrm{R}$ - with bioremediation

*values marked by different letters in columns are statistically different $(\alpha=0.05)$

Tabela 2. Wpływ związków ropopochodnych na powierzchnię wyżerek liści u roślin powodowanych przez Sitona spp. po upływie 3 i 5 lat od momentu zanieczyszczenia gleby $\left[\mathrm{mm}^{2}\right]$

Table 2. The effect of petroleum-derived substances on the feeds surface of the leaf per plant caused by Sitona spp. 3 and 5 years after the soil contamination $\left[\mathrm{mm}^{2}\right]$

\begin{tabular}{|c|c|c|c|c|c|c|c|c|}
\hline \multirow[b]{2}{*}{$\begin{array}{l}\text { Obiekt } \\
\text { Object }\end{array}$} & \multicolumn{2}{|c|}{$\begin{array}{l}1 \text { obserwacja } \\
1 \text { st observation }\end{array}$} & \multicolumn{2}{|c|}{$\begin{array}{c}2 \text { obserwacja } \\
2 \text { nd observation }\end{array}$} & \multicolumn{2}{|c|}{$\begin{array}{c}3 \text { obserwacja } \\
\text { 3th observation }\end{array}$} & \multicolumn{2}{|c|}{$\begin{array}{c}4 \text { obserwacja } \\
\text { 4th observation }\end{array}$} \\
\hline & $\begin{array}{c}3 \text { rok po zanie- } \\
\text { czyszczeniu } \\
\text { 3rd year after } \\
\text { contamination }\end{array}$ & $\begin{array}{l}5 \text { rok po zanie- } \\
\text { czyszczeniu } \\
5 \text { th year after } \\
\text { contamination }\end{array}$ & $\begin{array}{l}3 \text { rok po zanie- } \\
\text { czyszczeniu } \\
3 \text { rd year after } \\
\text { contamination }\end{array}$ & $\begin{array}{c}5 \text { rok po zanie- } \\
\text { czyszczeniu } \\
\text { 5th year after } \\
\text { contamination }\end{array}$ & $\begin{array}{c}3 \text { rok po zanie- } \\
\text { czyszczeniu } \\
\text { 3rd year after } \\
\text { contamination }\end{array}$ & $\begin{array}{l}5 \text { rok po zanie- } \\
\text { czyszczeniu } \\
5 \text { th year after } \\
\text { contamination }\end{array}$ & $\begin{array}{c}3 \text { rok po zanie- } \\
\text { czyszczeniu } \\
\text { 3rd year after } \\
\text { contamination }\end{array}$ & $\begin{array}{l}5 \text { rok po zanie- } \\
\text { czyszczeniu } \\
5 \text { th year after } \\
\text { contamination }\end{array}$ \\
\hline OS OR & $40,51 \mathrm{ab}^{*}$ & $41,25 \mathrm{a}$ & $107,03 \mathrm{ab}$ & $113,12 \mathrm{a}$ & $261,72 b$ & $220,54 \mathrm{a}$ & $476,65 b$ & $365,21 \mathrm{a}$ \\
\hline OS R & $33,52 \mathrm{a}$ & $72,86 \mathrm{~cd}$ & $49,73 \mathrm{a}$ & $256,39 \mathrm{c}$ & $120,18 \mathrm{a}$ & $410,86 c$ & $281,62 \mathrm{a}$ & $557,32 \mathrm{~b}$ \\
\hline ON OR & $48,71 \mathrm{ab}$ & $50,14 \mathrm{ab}$ & $135,70 \mathrm{bc}$ & $166,42 \mathrm{ab}$ & $254,81 \mathrm{~b}$ & $263,65 \mathrm{ab}$ & $395,08 \mathrm{ab}$ & $405,69 a$ \\
\hline ON R & $26,34 \mathrm{a}$ & $68,49 \mathrm{bc}$ & $75,05 \mathrm{ab}$ & $261,45 \mathrm{~cd}$ & $259,21 b$ & $324,58 \mathrm{bc}$ & $512,57 \mathrm{~b}$ & $621,82 \mathrm{~b}$ \\
\hline B $0 \mathrm{R}$ & $74,34 \mathrm{c}$ & $61,87 \mathrm{abc}$ & $317,61 \mathrm{e}$ & $163,16 \mathrm{a}$ & $850,70 \mathrm{e}$ & $307,56 \mathrm{~b}$ & $1363,74 \mathrm{~d}$ & $589,36 \mathrm{~b}$ \\
\hline B R & $72,42 \mathrm{c}$ & $78,18 \mathrm{~d}$ & $208,22 \mathrm{~d}$ & $320,24 \mathrm{~d}$ & $408,36 \mathrm{c}$ & $612,84 \mathrm{e}$ & $760,59 \mathrm{c}$ & $1238,54 \mathrm{~d}$ \\
\hline $\mathrm{K} 0 \mathrm{R}$ & $63,00 \mathrm{bc}$ & $74,12 \mathrm{~cd}$ & $192,01 \mathrm{~cd}$ & $248,49 \mathrm{c}$ & $417,54 \mathrm{c}$ & $549,63 \mathrm{~d}$ & $732,37 \mathrm{c}$ & $1023,05 \mathrm{c}$ \\
\hline K R & $82,54 \mathrm{c}$ & $68,59 \mathrm{bc}$ & $272,16 \mathrm{e}$ & $227,58 \mathrm{bc}$ & $517,37 \mathrm{~d}$ & $550,48 d$ & $1193,20 \mathrm{~d}$ & $1035,27 \mathrm{c}$ \\
\hline
\end{tabular}

OS - gleba zanieczyszczona olejem silnikowym, ON - olejem napędowym, B - benzyną, K - kontrola, $0 \mathrm{R}$ - bez bioremediacji, $\mathrm{R}$ - z bioremediacją *wartości oznaczone różnymi literami w kolumnach różnią się od siebie istotnie przy $\alpha=0,05$

OS - soil contaminated with engine oil, ON - soil contaminated with diesel oil, B - soil contaminated with petrol, K - control soil, 0R - without bioremediation, $\mathrm{R}$ - with bioremediation

*values marked by different letters in columns are statistically different $(\alpha=0.05)$ 
Tabela 3. Wpływ związków ropopochodnych na ubytek blaszki liściowej powodowany przez Sitona spp. po upływie 3 i 5 lat od momentu zanieczyszczenia gleby [\%]

Table 3. The effect of petroleum-derived substances on the loss of leaf blade caused by Sitona spp. 3 and 5 years after the soil contamination [\%]

\begin{tabular}{|c|c|c|c|c|c|c|c|c|}
\hline \multirow[b]{2}{*}{$\begin{array}{l}\text { Obiekt } \\
\text { Object }\end{array}$} & \multicolumn{2}{|c|}{$\begin{array}{l}1 \text { obserwacja } \\
1 \text { st observation }\end{array}$} & \multicolumn{2}{|c|}{$\begin{array}{c}2 \text { obserwacja } \\
2 \text { nd observation }\end{array}$} & \multicolumn{2}{|c|}{$\begin{array}{c}3 \text { obserwacja } \\
\text { 3th observation }\end{array}$} & \multicolumn{2}{|c|}{$\begin{array}{c}4 \text { obserwacja } \\
4 \text { th observation }\end{array}$} \\
\hline & $\begin{array}{c}3 \text { rok po } \\
\text { zanieczysz- } \\
\text { czeniu } \\
\text { 3rd year after } \\
\text { contamination }\end{array}$ & $\begin{array}{c}5 \text { rok po } \\
\text { zanieczysz- } \\
\text { czeniu } \\
\text { 5th year after } \\
\text { contamination }\end{array}$ & $\begin{array}{c}3 \text { rok po } \\
\text { zanieczysz- } \\
\text { czeniu } \\
\text { 3rd year after } \\
\text { contamination }\end{array}$ & $\begin{array}{c}5 \text { rok po } \\
\text { zanieczysz- } \\
\text { czeniu } \\
5 \text { th year after } \\
\text { contamination }\end{array}$ & $\begin{array}{c}3 \text { rok po } \\
\text { zanieczysz- } \\
\text { czeniu } \\
\text { 3rd year after } \\
\text { contamination }\end{array}$ & $\begin{array}{c}5 \text { rok po } \\
\text { zanieczysz- } \\
\text { czeniu } \\
\text { 5th year after } \\
\text { contamination }\end{array}$ & $\begin{array}{c}3 \text { rok po } \\
\text { zanieczysz- } \\
\text { czeniu } \\
\text { 3rd year after } \\
\text { contamination }\end{array}$ & $\begin{array}{c}5 \text { rok po } \\
\text { zanieczysz- } \\
\text { czeniu } \\
\text { 5th year after } \\
\text { contamination }\end{array}$ \\
\hline OS OR & $1,07 b c^{*}$ & $1,17 \mathrm{a}$ & $1,03 \mathrm{bc}$ & $1,14 \mathrm{a}$ & $0,80 \mathrm{bc}$ & $0,92 \mathrm{a}$ & $0,82 \mathrm{~cd}$ & $0,71 \mathrm{a}$ \\
\hline OS R & $0,88 \mathrm{ab}$ & $2,51 \mathrm{~d}$ & $0,30 \mathrm{a}$ & $2,47 \mathrm{~d}$ & $0,31 \mathrm{a}$ & $1,65 \mathrm{c}$ & $0,40 \mathrm{a}$ & $1,14 \mathrm{~b}$ \\
\hline ON OR & $0,93 \mathrm{ab}$ & $1,41 \mathrm{ab}$ & $0,63 \mathrm{~b}$ & $1,27 \mathrm{a}$ & $0,60 \mathrm{~b}$ & $0,96 \mathrm{a}$ & $0,53 \mathrm{ab}$ & $0,82 \mathrm{a}$ \\
\hline ON R & $0,61 \mathrm{a}$ & $2,12 \mathrm{c}$ & $0,41 \mathrm{ab}$ & $1,91 \mathrm{bc}$ & $0,63 \mathrm{bc}$ & $1,17 \mathrm{ab}$ & $0,70 \mathrm{bc}$ & $1,21 \mathrm{bc}$ \\
\hline B OR & $1,15 \mathrm{bc}$ & $1,24 \mathrm{a}$ & $1,37 \mathrm{~d}$ & $1,05 \mathrm{a}$ & $1,53 \mathrm{e}$ & $1,12 \mathrm{ab}$ & $1,39 \mathrm{f}$ & $0,92 \mathrm{ab}$ \\
\hline B R & $1,52 \mathrm{c}$ & $2,15 \mathrm{c}$ & $1,07 \mathrm{c}$ & $2,12 \mathrm{~cd}$ & $0,83 \mathrm{c}$ & $1,47 \mathrm{bc}$ & $0,92 \mathrm{~d}$ & $1,29 \mathrm{c}$ \\
\hline K 0R & $0,96 \mathrm{ab}$ & $1,63 \mathrm{bc}$ & $0,72 b$ & $1,38 \mathrm{a}$ & $0,75 \mathrm{bc}$ & $1,14 \mathrm{ab}$ & $0,73 \mathrm{~cd}$ & $0,95 \mathrm{ab}$ \\
\hline K R & $1,32 \mathrm{bc}$ & $1,48 \mathrm{ab}$ & $1,04 \mathrm{c}$ & $1,42 \mathrm{ab}$ & $0,92 \mathrm{~d}$ & $0,99 \mathrm{ab}$ & $1,13 \mathrm{e}$ & $1,08 \mathrm{~b}$ \\
\hline
\end{tabular}

OS - gleba zanieczyszczona olejem silnikowym, ON - olejem napędowym, B - benzyną, K - kontrola, 0R - bez bioremediacji, $\mathrm{R}$ - z bioremediacją *wartości oznaczone różnymi literami w kolumnach różnią się od siebie istotnie przy $\alpha=0,05$

OS - soil contaminated with engine oil, ON - soil contaminated with diesel oil, $\mathrm{B}$ - soil contaminated with petrol, $\mathrm{K}$ - control soil, 0R - without bioremediation, $\mathrm{R}$ - with bioremediation

*values marked by different letters in columns are statistically different $(\alpha=0.05)$

Podobną zależność odnotowano również w przypadku benzyny, jednak tylko w piątym roku. W trzecim roku po zanieczyszczeniu substancja ta najczęściej przyczyniała się do istotnego wzrostu ubytku blaszki liściowej u roślin rosnących na glebie zanieczyszczonej. Biopreparat ZB-01 w trzecim roku po zastosowaniu spowodował zmniejszenie ubytku blaszki liściowej u roślin rosnących na glebie zanieczyszczonej olejem silnikowym i benzyną już podczas drugiego terminu prowadzonych obserwacji, z kolei $\mathrm{u}$ roślin rosnących na glebie kontrolnej odnotowano najczęściej istotny wzrost wartości analizowanego parametru pod wpływem bioremediacji. Po upływie dwóch kolejnych lat, u roślin rosnących $\mathrm{w}$ warunkach gleby zanieczyszczonej wszystkimi substancjami ropopochodnymi poddanej procesowi bioremediacji odnotowano wzrost ubytku blaszki liściowej spowodowany przez chrząszcze w porównaniu do obiektów, w których nie zastosowano biopreparatu. W przypadku kontroli nie odnotowano istotnego wpływu procesu bioremediacji na analizowaną cechę.

Dotychczas nie prowadzono badań dotyczących wpływu związków ropopochodnych na występowanie i żerowanie oprzędzików. Występujące w niniejszym doświadczeniu zależności można jednak częściowo tłumaczyć odnosząc się do badań nad innymi rodzajami zanieczyszczeń gleby, np. metalami ciężkimi, gdyż substancje ropopochodne przyczyniają się do zwiększenia ich zawartości w glebie (Ujowundu i wsp. 2011; Wyszkowski i Sivitskaya 2012). Gospodarek (2012) w swoich badaniach stwierdziła, że zanieczyszczenie gleby mieszaniną cynku z niklem oraz mieszanina tych metali z miedzią, ołowiem lub kadmem na poziomie III stopnia zanieczyszczenia prowadzi do istotnego ograniczenia żerowania oprzędzików. Podobnie w niniejszym doświadczeniu, olej silnikowy, olej napędowy oraz benzyna (w piątym roku po zanieczyszczeniu) powodowały najczęściej zmniejszenie odsetka liści uszkodzonych przez chrząszcze oraz zmniejszenie powierzchni wyżerek. Gospodarek (2011) wykazała również, że po upływie trzech lat od momentu zanieczyszczenia gleby $\mathrm{Zn}, \mathrm{Ni}, \mathrm{Cd}, \mathrm{Cu}$ lub $\mathrm{Pb}$ nie odnotowano wzrostu atrakcyjności roślin bobu dla oprzędzików.

Substancje ropopochodne często powodują osłabienie wzrostu i rozwoju roślin uprawnych, a także modyfikują w nich zawartość makro- i mikroelementów, co może doprowadzić do pogorszenia jakości pokarmu szkodników (zmniejszenie zawartości azotu, fosforu, białka, chlorofilu) (Nadgórska-Socha i wsp. 2005; Rusin i wsp. 2015), a co się z tym wiąże może modyfikować proces zasiedlania przez nie roślin uprawnych. Jaworska i Gospodarek (2003) stwierdziły, że dorosłe oprzędziki częściej zasiedlają rośliny zdrowe, co pokrywa się z wynikami niniejszego doświadczenia.

W dostępnej literaturze jest niewiele informacji dotyczących wpływu bioremediacji wspomaganej na bezkręgowce, a wyniki dotyczą głównie organizmów glebowych. Badania te wskazują jednak, że może ona niwelować negatywny wpływ substancji ropopochodnych (Gospodarek i Rusin 2015; Gospodarek i wsp. 2016). W niniejszym doświadczeniu podobny efekt oddziały- 
wania biopreparatu odnotowano po upływie pięciu lat od momentu zanieczyszczenia gleby i jego użycia.

\section{Wnioski / Conclusions}

1. Olej napędowy i przepracowany olej silnikowy najczęściej przyczyniały się do ograniczenia odsetka roślin uszkodzonych przez oprzędziki oraz zmniejszenia powierzchni wyżerek na liściach, jednak w większości przypadków nie miały istotego wpływu na wielkość ubytku blaszki liściowej spowodowanego żerowaniem chrząszczy, co wynika z mniejszej powierzchni liści w tych obiektach w porównaniu do kontroli.

2. Oddziaływanie benzyny było zmienne, zależne od roku, w którym przeprowadzono badania. Po upływie trzech lat od momentu zanieczyszczenia (2013 rok) w obiekcie, w których zastosowano tę substancję, odnotowano wzrost intensywności żerowania szkodników, z kolei po upływie dwóch kolejnych lat (2015 rok), podobnie jak w przypadku pozostałych substancji ropopochodnych, jej spadek.
3. W kontenerach z zastosowaną bioremediacją po upływie trzech lat od momentu użycia zauważono ograniczenie żerowania analizowanych szkodników w obiektach zanieczyszczonych olejem silnikowym i benzyną, z kolei po upływie pięciu lat od momentu jej zastosowania odnotowano odwrotną zależność - biopreparat ZB-01 zastosowany na glebę zanieczyszczoną benzyną, olejem silnikowym i olejem napędowym przyczyniał się do wzrostu intensywności żerowania chrząszczy.

\section{Podziękowania / Acknowledgements}

Praca zrealizowana w ramach dotacji celowej na prowadzenie badań naukowych lub prac rozwojowych oraz zadań z nimi związanych, służących rozwojowi młodych naukowców oraz uczestników studiów doktoranckich Uniwersytetu Rolniczego finansowanych w trybie konkursowym w 2014 roku - nr tematu 4155 oraz z dotacji przyznanej przez Ministerstwo Nauki i Szkolnictwa Wyższego na działalność statutową.

\section{Literatura / References}

Caravaca F., Rodán A. 2003. Assessing changes in physical and biological properties in soil contaminated by oil sludges under semiarid Mediterranean conditions. Geoderma 117: 53-61.

Corre-Hellou G., Crozat Y. 2005. N2 fixation and N supply in organic pea (Pisum sativum L.) cropping system as affected by weeds and pea-weevil (Sitona lineatus L.). European Journal of Agronomy 22: 449-458.

Das N., Chandran P. 2011. Microbial degradation of petroleum hydrocarbon contaminants: an overview. Biotechnology Research International 1: 1-13.

Dor'e T., Meynard J.M. 1995. On-farm approach of attacks by the pea weevil (Sitona lineatus L., Col., Curculionidae) and the resulting damage to pea (Pisum sativum L.) crops. Journal of Applied Entomology 119: 49-54.

Gbadebo A.M., Adenuga M.D. 2012. Effect of crude oil on the emergence and growth of cowpea in two contrasting soil types from Abeokuta, southwestern Nigeria. Asian Journal of Applied Sciences 5 (4): 232-239.

Gospodarek J. 2011. Residual effect of soil contamination with heavy metals on Sitona sp. beetles feeding on broad bean (Vicia faba L.). Ecological Chemistry and Engineering A 18 (11): 1565-1570.

Gospodarek J. 2012. Atrakcyjność bobu dla oprzędzików (Sitona spp.) w warunkach zanieczyszczenia gleby mieszaninami metali ciężkich. [Attractiveness of broad bean for Sitona spp. in conditions of soil pollution with heavy metals mixtures]. Progress in Plant Protection/Postępy w Ochronie Roślin 52 (4): 791-795.

Gospodarek J., Petryszak P., Kołoczek H. 2016. The effect of the bioremediation of soil contaminated with petroleum derivatives on the occurrence of epigeic and edaphic fauna. Bioremediation Journal 20 (1): 38-53.

Gospodarek J., Rusin M. 2015. Residual effect of soil pollution with oil derivatives on the occurrence of Acarina. Proceedings of ECOpole 9 (1): 71-77.

Haritash A.K., Kaushik C.P. 2009. Biodegradation aspects of Polycyclic Aromatic Hydrocarbons (PAHs): A review. Journal of Hazardous Materials 169 (1-3): 1-15.

Houshmandfar A., Asli D.E. 2011. Seed germination and seedling growth of wheat, barley, alfalfa and clover as affected by gasoline and diesel fuel mixture. Advances in Environmental Biology 5 (6): 1250-1255.

Iturbe R., Flores C., Castro A., Torres L.G. 2007. Sub-soil contamination due to oil spills in zones surrounding oil pipeline-pump stations and oil pipeline right-of-ways in Southwest-Mexico. Environmental Monitoring and Assessment 133 (1-3): 387-398.

Jaworska M., Gospodarek J. 2003. Effect of soil contamination with heavy metals on harmfulness of Sitona and Bruchus rufimanus Boh. on broad bean (Vicia faba L. ssp. maior). Chemia i Inżynieria Ekologiczna 10 (3-4): 291-295.

Liste H., Felgentreu D. 2006. Crop growth, culturable bacteria and degradation of petrol hydrocarbons (PHCs) in a long-term contaminated field soil. Applied Soil Ecology 31: 43-52.

Milić J.S., Beškoski V.P., Ilić M.V., Ali S.A.M., Gojgić-Cvijović G.D., Vrvić M.M. 2009. Bioremediation of soil heavily contaminated with crude oil and its products: composition of the microbial consortium. Journal of Serbian Chemical Society 74 (4): $455-460$.

Nadgórska-Socha A., Gospodarek J., Jaworska M., Ciepał R. 2005. Content of assimilation pigments, phosphorus and protein in broad bean Vicia faba L. ssp. maior grown in heavy metals contaminated soils. Chemia i Inżynieria Ekologiczna 12 (4): 421-426.

Ogbo E.M. 2009. Effects of diesel fuel contamination on seed germination of four crop plants - Arachis hypogaea, Vigna unguiculata, Sorghum bicolor and Zea mays. African Journal of Biotechnology 8 (2): 250-253.

Onwurah I.N.E., Ogugua V.N., Onyike N.B., Ochonogor A.E., Otitoju O.F. 2007. Crude oil spills in the environment, effects and some innovative clean-up biotechnologies. International Journal of Environmental Research 1 (4): 307-320. 
Rusin M., Gospodarek J., Nadgórska-Socha A. 2015. The effect of petroleum-derived substances on the growth and chemical composition of Vicia faba L. Polish Journal of Environmental Studies 24 (5): 2157-2166.

Strażyński P. 2013. Dynamika występowania oprzędzika pręgowanego (Sitona lineatus L.) na uprawach grochu siewnego i bobiku na wybranych stanowiskach w Wielkopolsce. [The dynamics of the occurence of pea leaf weevil (Sitona lineatus L.) on pea and faba bean crops on selected localities in Wielkopolska]. Progress in Plant Protection/Postępy w Ochronie Roślin 53 (4): 709-712.

Sutton N.B., Maphosa F., Morillo J.A., Abu Al-Soud W., Langenhoff A.A., Grotenhuis T., Rijnaarts H.H., Smidt H. 2013. Impact of long-term diesel contamination on soil microbial community structure. Applied and Environmental Microbiology 79 (2): 619-630.

Ujowundu C.O., Kalu F.N., Nwaoguikpe R.N., Kalu O.I., Ihejirika C.E., Nwosunjoku E.C., Okechukwu R.I. 2011. Biochemical and physical characterization of diesel petroleum contaminated soil in southeastern Nigeria. Research Journal of Chemical Science 1 (8): $57-62$.

Wyszkowski M., Sivitskaya V. 2012. Changes in the content of organic carbon and available forms of macronutrients in soil under the influence of soil contamination with fuel oil and application of different substances. Journal of Elementology 17 (1): 139-148.

Wyszkowska J., Wyszkowski M. 2010. Activity of soil dehydrogenases, urease, and acid and alkaline phosphatases in soil polluted with petroleum. Journal of Toxicology and Environmental Health A 73 (17-18): 1202-1210.

Ziółkowska A., Wyszkowski M. 2010. Toxicity of petroleum substances to microorganism and plants. Ecological Chemistry and Engineering S 17 (1): 73-82. 